\title{
Impact of Economic Crisis on Changes in Motivation of Employees in Woodworking Industry
}

\section{Utjecaj ekonomske krize na motivaciju zaposlenika u tvrtkama drvne industrije}

\author{
Original scientific paper • Izvorni znanstveni rad \\ Received-prispjelo: 9. 1. 2013. \\ Accepted-prihvaćeno: 6. 2. 2014. \\ UDK: $630 * 7 ; 65.015$ \\ doi:10.5552/drind.2014.1303
}

\begin{abstract}
The paper deals with the motivation of employees of a woodworking enterprise and analyses the level of individual motivation before (2004) and after the economic crisis and its effects in Slovakia (2012). The aim of the paper is to identify the most important motivation factors for employees and to consider the impact of financial crisis on the change in perception of individual motivation factors and their economic and social impact on employees. A questionnaire, as a method of inquiry, was used to acquire relevant data. Descriptive and testing statistics were used for data processing. Significance level $p$ was computed for individual motivation factors for the year 2004 and 2012 by means of T-test. The objective of this paper is to define significant change of average rate of individual motivation factors and to compare the order of importance of motivation factors before and after the economic crisis. Based on our research it can be stated that the world economic crisis has no impact on the level of employee motivation in the selected enterprise.
\end{abstract}

Key words: motivation, motivational programme, changes of motivation, economic crisis, T-test

SAŽETAK • Autori se bave motivacijom zaposlenih u tvrtkama za preradu drva i analizom razina pojedinih motivacijskih čimbenika prije početka ekonomske krize (2004) i nakon što je ona zahvatila Slovačku i postala ozbiljna. Cilj rada je definirati najvažnije čimbenike motivacije zaposlenika te utjecaj ekonomske krize na promjenu važnosti pojedinih motivacijskih utjecaja, pri čemu je naglasak na ekonomskim i socijalnim čimbenicima. Da bi se prikupili relevantni podaci primijenjena je metoda anketiranja odnosno upitnika, a za obradu i testiranje podataka poslužila je statistika. Pri korištenju T-testa izračunavana je značajna razina p za pojedine motivacijske čimbenike u razdoblju od 2004. do 2012. godine. Rezultat istraživanja jest definiranje značajne razlike srednje vrijednosti pojedinih motivacijskih čimbenika i usporedba njihovih vrijednosti prije i nakon nastanka ekonomske krize. Na temelju ovog istraživanje može se utvrditi da ekonomska kriza nema utjecaja na razinu motiviranosti zaposlenika u promatranim poduzećima.

Ključne riječi: motivacija, motivacijski program, promjene u motivaciji, ekonomska kriza, T-test

\footnotetext{
${ }^{1}$ Authors are associate professor, assistant and lecturer at Faculty of Wood Sciences and Technology, Technical University in Zvolen, Zvolen, Slovakia.

${ }^{1}$ Autori su izvanredni profesor, asistent i predavač Fakulteta znanosti o drvu i drvne tehnologije, Tehničko sveučilište u Zvolenu, Zvolen, Slovačka.
} 


\section{INTRODUCTION}

\section{UVOD}

Market globalisation, lack of qualified workforce and financial crisis present permanent pressure on the enterprise management, which must be focused on developing a competitive strategy as well as on determining and implementing crisis management to keep the enterprise going. The enterprise can have high technology, dispose of vast financial resources and precious information but only qualified and skilled employees will make decisions and ensure success and competitiveness of the enterprise (Hitka and Sirotiaková, 2011).

As a result of recent changes in the economic structure, i.e. the adaptation of the Slovak economy to market conditions, enterprises pay more attention to man and his personal traits. As the only source of innovation and progress, the employee can use new opportunities, markets and up-to-date technologies. The above mentioned changes can also be observed in the area of woodworking industry (Jelačić et al., 2012). Prosperity and enterprise competitive advantage in the market can be ensured by human factor that also determines the operations of the production process, its results and human behaviour. Since the significance of the human factor has been underestimated in the production process management where machines and technology dominate, changes will occur in personnel position and responsibilities and increasing attention will be placed on personal traits as the reaction of enterprises to changed market conditions (Blašková, 2011). Some changes in the area of motivation could be observed in the research conducted in Slovenia and Croatia (Kropivšek et al., 2011). When a company wants to be in a position to perform these changes, it is necessary to motivate employees, i.e. to appeal to intrinsic motivation by selected motivational tools and ways. Some methods can be used to manage the period of crisis by means of non-financial rewards of employees - to restructure teams, arrange educational activities within the enterprise, train employees, offer language and IT courses, management training, professional courses, seminars and trainings, and to benefit from some outsourcing tools (Potkány, 2008). Many sports activities and various corporate events can be carried out by the enterprise to improve interpersonal skills, too. It is also important to encourage corporate communication especially towards subordinates. Additional forms of non-financial motivation show employee recognition and appreciation and improve employee empowerment. Selection of non-financial rewards should be made by employees. Another way of employee motivation is self-actualization, which means delegation of some competences and re- sponsibilities. However, employees can also be motivated by changes in the enterprise management system. Benefits and motivation programmes, by which employees can meet their needs of self-actualization or their economic requirements, can also be effective. The employees' potential can be started by effective nomoney tools (Vetráková et al., 2001).

In the current economic situation, which is influenced by ongoing economic crisis, it is necessary to think about employee motivation in connection to work performance and to analyze this relationship consistently. To do so, it is essential for the enterprise employees to know the motivation factors. Therefore, the aim of this paper is to find out how employees of the selected woodworking enterprise evaluate their job position, how they feel at work and what the structure of their needs is, i.e. to identify their most important motivation factors. Considering the above mentioned factor, i.e. the ongoing economic crisis, the impact of the crisis on changes in motivation of employees in woodworking industry was observed.

\section{MATERIAL AND METHODS}

\section{MATERIJAL I METODE}

A general questionnaire was used as a tool of inquiry to analyze the motivation factors of employees in woodworking industry. Analysis of the motivation factors of enterprise employees was carried out in the year 2004 and 2012. The analysis was repeated in order to consider the impact of economic crisis on motivation of employees of the selected enterprise. The questionnaire consisted of 30 closed questions (Hitka, 2010). In order to be easily understood, it was created in a simple version for all categories of employees. The questionnaire was divided into two parts. The first part was focused on socio-demographic and qualification characteristics of employees. Information about respondents related to their age, sex, years of work in the enterprise, completed education and job position were acquired. Individual motivation factors were determined and used for acquiring information about characteristics of work environment, working conditions, employee appraisal and reward system, about human resources management, health and social care system and system of employee benefits. Information about employee satisfaction or dissatisfaction, value orientation, relation to work and enterprise or co-workers' relationship were included in the second part of the questionnaire. In order not to affect the respondents, individual motivation factors were ordered alphabetically. The employees could mark each question item with only one of five degrees of importance from the evaluation scale stated in Tab. 1.

Table 1 Scale of importance of motivation factors (Hitka, 2010)

Tablica 1. Ocjena važnosti motivacijskih čimbenika (Hitka, 2010)

\begin{tabular}{|c|c|c|c|c|}
\hline 5 & 4 & 3 & 2 & 1 \\
\hline $\begin{array}{c}\text { the most important } \\
\text { najvažnije }\end{array}$ & $\begin{array}{c}\text { very important } \\
\text { vrlo važno }\end{array}$ & $\begin{array}{c}\text { medium important } \\
\text { srednje važno }\end{array}$ & $\begin{array}{c}\text { slightly important } \\
\text { manje važno }\end{array}$ & $\begin{array}{c}\text { Unimportant } \\
\text { nevažno }\end{array}$ \\
\hline
\end{tabular}


Questionnaires were evaluated by the programme STATISTICA 7. For describing the sets (the year 2004, the year 2012), descriptive statistics was used. Statistical characteristics, which compressed information about the observed sets into a smaller number of numerical characteristics making easier the comparison of sets, were computed for each motivation factor. Each motivation factor was summarily described by the basic characteristics of size and variability of quantitative features - arithmetic mean, standard deviations and coefficients of variation.

Besides the simple comparison of descriptive characteristic values, testing statistics was used to consider the impact of economic crisis on employee motivation. The purpose of statistical testing was to determine whether the impact of economic crisis caused statistically significant differences in perception of importance of individual motivation factors among enterprise employees. To test the equality of arithmetic means of motivation factors of two basic sets (the year 2004, the year 2012), T-test was used. Null hypothesis and alternative hypothesis were tested; they were as follows:

H0: it is supposed that arithmetical means of motivation factors observed in the year 2004 and 2012 are equal and the difference between them, if any, is only caused by accidental score fluctuation, i.e. the economic crisis does not have any statistically significant effect on the change in perception of the importance of motivation factors in the year 2004;

$\mathrm{H1}$ : it is supposed that arithmetical means of motivation factors observed in the year 2004 and 2012 are not equal and the difference between them, if any, is not caused by accidental score fluctuation, i.e. the economic crisis has statistically significant effect on the change in perception of motivation factors in the year 2004

To verify the correctness of $H_{0}$, random variable was used as a test criterion, where $t$-division with the number of degrees of freedom $n-1$ in the form (Scheer, 2007):

$$
t=\frac{\bar{x}-\mu_{0}}{\frac{s_{X}}{\sqrt{n-1}}}
$$

At the end of the test, $t$ was compared with $t_{\alpha} / 2 ; f$, in case $t \leq t_{\alpha / 2} ; f, H_{0}$ was accepted and the difference was not considered significant, and on the contrary if $t>t_{\alpha} / 2 ; f, H_{0}$ was refused at $\alpha \%$ level of significance, and the alternative hypothesis $H_{1}$ was accepted.

\section{RESULTS}

\section{REZULTATI}

Despite the above analysis and recommendations from the year 2004 (after carrying out analysis 1), at present there is no motivational programme in the analysed enterprise. Individual motivation factors are incorporated into collective agreement and especially the following motivation factors: basic salary, further financial reward (extra performance pay, special pay, personal bonus, anniversary and jubilee bonus), job security, work environment improvement, social benefits (transport allowance, meal allowance, holiday entitlement, supplementary retirement savings), education and personal growth.

Basic information about respondents related to their age, sex, years of work in the enterprise, completed education and job position were analysed in the first part of the questionnaire. Due to its length, the evaluation of this part of the questionnaire is not presented in this paper. Individual motivation factors were observed in the second part of the questionnaire. The most important motivation factors from the point of view of employees in the year 2004 are presented in Tab. 2. Based on the obtained mean values, it is possible to say that, from the point of view of employees, the most important motivation factors are the basic salary and further financial rewards. Differences in the obtained mean values of significance level of these factors are negligible $(\Delta 0.01)$. Further to the above, it can be stated that the financial motivation (i.e. financial reward) was the best motivation for employees at the time before the economic crisis, too. The survey also showed the fact that job security was also very important for the employees of the analysed enterprise. It can be related with the position of the enterprise. At that time the unemployment rate in the area of the enterprise was $18.1 \%$. According to motivation theories (Blašková, 2011), employee satisfaction can be increased if the employer pursues a fair social policy and appraisal system. This fact was also confirmed by the above mentioned survey of motivation in the woodworking industry. According to employees of the analysed enterprise, the motivation factors that follow those related to employees rewarding, are - social benefits, e.g. health care and rehabilitation services, housing policy, meal allowance, cultural and community care provided for employees and family members, employee child care, sale of products at discount price and offering loans. It was followed by motivation factors like atmosphere at workplace and good working team, which represent an important role in human life. It means that good atmosphere at workplace and good workplace relations significantly affect the employee satisfaction at work. 
Table 2 The most important motivation factors in the year 2004

Tablica 2. Najvažniji motivacijski čimbenici u 2004. godini

\begin{tabular}{|c|l|c|}
\hline S.N. & Motivation factor / Motivacijski čimbenik & $\varnothing$ \\
\hline 1. & Basic salary / osnovna plaća & 4.69 \\
\hline 2. & Further financial reward / dodatna financijska nagrada & 4.68 \\
\hline 3. & Job security / sigurnost radnog mjesta & 4.65 \\
\hline 4. & Social benefits / socijalne naknade & 4.57 \\
\hline 5. & Atmosphere at workplace / atmosfera na radnome mjestu & 4.55 \\
\hline 5. & Good working team / dobar radni tim & 4.51 \\
\hline 7. & Fair appraisal system / pošten sustav ocjenjivanja & 4.48 \\
\hline 8. & Supervisor' s approach / supervizorski pristup & 4.45 \\
\hline 9. & Opportunity to use own abilities / mogućnost iskazivanja sposobnosti & 4.33 \\
\hline 10. & Prestige / prestiž & 4.31 \\
\hline
\end{tabular}

In the year 2012, the basic salary remained the most important motivation factor (Tab. 3). It became even more important because of bad economic situation and indebtedness of people caused by the economic crisis. Reduced savings due to rising prices of most consumer goods, and reduced basic salaries following the reduced demand for products and services result in reduced purchasing power of people. For employees, the second most important motivation factor was social benefits. Social benefits, like the above stated standard services provided to employees by the enterprise, can be an important saving money factor related with the job, providing e.g. transport, meals, retraining courses or offering different services, relaxation and recreation important for physical and psychological regeneration. The next motivation factors were job security followed by good working team, highlighting the need of togetherness and good workplace relations. The fifth most important motivation factor was further financial reward confirming the significance of finances at the time of economic recession.

Table 3 The most important motivation factors in the year 2012

Tablica 3. Najvažniji motivacijski čimbenici u 2012. godini

\begin{tabular}{|c|l|c|}
\hline S.N. & Motivation factor / Motivacijski čimbenik & $\varnothing$ \\
\hline 1. & Basic salary / osnovna plaća & 4.82 \\
\hline 2. & Social benefits / socijalne naknade & 4.67 \\
\hline 3. & Job security / sigurnost radnog mjesta & 4.65 \\
\hline 4. & Good working team / dobar radni tim & 4.57 \\
\hline 5. & Further financial reward / dodatna financijska nagrada & 4.55 \\
\hline 6. & Work environment / radno okruženje & 4.43 \\
\hline 6. & Work performance / izvedba poslova & 4.43 \\
\hline 8. & Self - actualization / samoaktualizacija & 4.42 \\
\hline 9. & Supervisor' s approach / supervizorski pristup & 4.38 \\
\hline 10. & Fair appraisal system / pošten sustav ocjenjivanja & 4.31 \\
\hline
\end{tabular}

Even though by comparing the levels of motivation in the year 2004 and 2012, changes in mean values arise, significant change of motivation factors $(p<0.05)$ arises only in connection with factors like working hours, moving up the corporate ladder, competences, prestige, social benefits, region development (Tab. 4). In spite of the expectations that, due to the economic crisis, the employees' demands would change and that they would be willing to work in worse working conditions, our assumptions did not prove true.
Based on the actual survey of employee motivation (Hitka, 2009a, 2009b), it can be stated that employees in manufacturing enterprises have generally kept the level of motivation during 5-6 years. Assumptions that, due to the world economic crisis and its economic and social impacts, the motivation level of employees in the woodworking industry would change significantly, did not prove true. Moreover, the order of motivation factors did not change fundamentally. 
...... Hitka, Hajdukova, Balážová: Impact of Economic Crisis on Changes in Motivation ...

Table 4 Comparison of the significance of motivation change in the year 2004 and 2012

Tablica 4. Usporedba značenja motivacijskih čimbenika u godinama 2004. i 2012.

\begin{tabular}{|c|c|c|c|c|}
\hline \multirow[t]{2}{*}{$\begin{array}{l}\text { Motivation factor } \\
\text { Motivacijski čimbenik }\end{array}$} & $\begin{array}{c}\text { Mean } \\
\text { Srednja } \\
\text { vrijednost }\end{array}$ & $\begin{array}{c}\text { Mean } \\
\text { Srednja } \\
\text { vrijednost }\end{array}$ & \multirow[t]{2}{*}{$\begin{array}{c}\text { t-value } \\
t \text {-vrijednost }\end{array}$} & \multirow[t]{2}{*}{$p$} \\
\hline & 2004 & 2012 & & \\
\hline Atmosphere at workplace / atmosfera na radnome mjestu & 4.55 & 4.33 & 1.82 & 0.071 \\
\hline Good working team / dobar radni tim & 4.68 & 4.55 & 1.33 & 0.188 \\
\hline $\begin{array}{l}\text { Further financial reward }\left(13^{\text {th }}, 14^{\text {th }} \text { salary }\right) / \text { dodatna } \\
\text { financijska nagrada }\end{array}$ & 4.55 & 4.57 & -0.13 & 0.898 \\
\hline Physical effort at work / fizički napori na poslu & 3.53 & 3.70 & -0.95 & 0.345 \\
\hline Job security / sigurnost radnog mjesta & 4.65 & 4.65 & 0.00 & 1.000 \\
\hline Communication at workplace / komunikacija & 4.18 & 4.37 & -1.21 & 0.228 \\
\hline Company name / naziv tvrtke & 4.17 & 4.15 & 0.11 & 0.916 \\
\hline $\begin{array}{l}\text { Opportunity to use own abilities / mogućnost primjene } \\
\text { vlastitih sposobnosti }\end{array}$ & 4.33 & 4.18 & 1.13 & 0.261 \\
\hline $\begin{array}{l}\text { Workload and type of work done / radno opterećenje } i \\
\text { vrsta posla }\end{array}$ & 4.10 & 4.12 & -0.12 & 0.906 \\
\hline $\begin{array}{l}\text { Familiarisation with reached working results / upozna- } \\
\text { vanje s postignutim rezultatima }\end{array}$ & 3.98 & 4.18 & -1.25 & 0.212 \\
\hline Working hours / radno vrijeme & 3.82 & 4.17 & -2.09 & 0.039 \\
\hline Work environment / radno okruženje & 4.25 & 4.43 & -1.18 & 0.242 \\
\hline Work performance / izvedba poslova & 4.12 & 4.35 & -1.64 & 0.104 \\
\hline $\begin{array}{l}\text { Moving up corporate ladder / uspon na korporativnoj } \\
\text { ljestvici }\end{array}$ & 4.10 & 4.43 & -2.27 & 0.025 \\
\hline Competences / kompetencije & 4.12 & 3.75 & 2.31 & 0.023 \\
\hline Prestige / prestiž & 4.32 & 3.80 & 3.23 & 0.002 \\
\hline Supervisor's approach / supervizorski pristup & 4.45 & 4.38 & 0.49 & 0.624 \\
\hline $\begin{array}{l}\text { Individual decision making / samostalno donošenje } \\
\text { odluka }\end{array}$ & 4.25 & 4.13 & 0.96 & 0.339 \\
\hline Self-actualization / samoaktualizacija & 4.17 & 3.97 & 1.38 & 0.170 \\
\hline $\begin{array}{l}\text { Social benefits (utilisation of social fund) / društvene } \\
\text { koristi (korištenje socijalnog fonda) }\end{array}$ & 4.00 & 4.42 & -2.60 & 0.010 \\
\hline Fair appraisal system / pošten sustav ocjenjivanja & 4.57 & 4.67 & -0.65 & 0.518 \\
\hline Stress / stres & 4.48 & 4.38 & 0.70 & 0.488 \\
\hline Mental effort / mentalni napor & 4.05 & 4.32 & -1.57 & 0.119 \\
\hline Company vision / vizija tvrtke & 4.12 & 4.27 & -0.92 & 0.359 \\
\hline Region development / razvoj regije & 3.85 & 4.23 & -2.25 & 0.026 \\
\hline Education and personal growth / obrazovni i osobni rast & 4.18 & 4.25 & -0.49 & 0.627 \\
\hline $\begin{array}{l}\text { Company relation to environment / odnos tvrtke prema } \\
\text { okolišu }\end{array}$ & 4.13 & 4.33 & -1.36 & 0.176 \\
\hline Free time / slobodno vrijeme & 3.97 & 4.18 & -1.18 & 0.240 \\
\hline Recognition / priznanje & 4.27 & 4.28 & -0.11 & 0.913 \\
\hline Basic salary / osnovna plaća & 4.68 & 4.82 & -1.06 & 0.291 \\
\hline
\end{tabular}

Significant changes are in bold / značajne promjene su otisnute poludebelim slovima 


\section{CONCLUSION}

\section{ZAKLJUČAK}

As indicated in the introduction of this paper, the source of the entire activity, productivity and prosperity of enterprises lies in human resources. Therefore, enterprises should provide working conditions for their employees that can ensure a suitable level of employee motivation. It is a general truth that even the best employee must not only be able to work - to have suitable skills for the given work, but he must also want to work - which implies that the level of his motivation to work and his willingness to work is high. The basic conditions to improve work performance and achieve goals related to personnel performance, especially at the time of the economic crisis, is to know different methods and forms of motivation and their implementation in the working process.

The aim of this paper was to consider the effect of the world economic crisis and its economic and social impacts on the change in employee motivation in the selected woodworking enterprise. The analysis of motivation factors was carried out in the analysed enterprise by the method of inquiry in the year 2004 and 2012. The acquired data were evaluated through methods and tools of descriptive and testing statistics. The research results show that the order of importance of motivation factors, developed on the basis of the obtained mean value, changed and however significant change in perception of importance of individual motivation factors arose only in $20 \%$ of factors, i.e. in 6 out of 30 factors. Significant change occurred in connection with factors like working hours, moving up the corporate ladder, competences, social benefits and region development (Tab. 4). The most important finding of the survey, resulting from statistical testing, is that the effect of the world economic crisis, and its economic and social impacts, does not lead to a significant change in the level of employee motivation in woodworking industry.

\section{REFERENCES}

\section{LITERATURA}

1. Blašková, M., 2011: Rozvoj ludského potenciálu - motivovanie, komunikovanie, harmonizovanie a rozhodovanie. Žilinská univerzita v Žiline. Žilina, p. 390.

2. Hitka, M., 2009a: Model analýzy motivácie zamestnancov výrobných podnikov. Vedecká monografia, ES TU Zvolen. Zvolen, p. 150.

3. Hitka, M., 2009b: Zhodnotenie výskumu motivácie zamestnancov vo výrobných podnikoch Slovenska za roky 2000-2008. Medzinárodná vedecká konferencia MLPvP. Žilina.

4. Hitka, M., 2010: Výsledky diagnostikovania motivačného prostredia THP zamestnancov v ŽOS a. s. Zvolen. Ekonomické rozhlady 3/2005. p. 384-390.

5. Hitka, M.; Sirotiaková, M., 2011: Impact of Economic Crisis on Change of Motivation of Ekoltech s. r. o. Filakovo Employees. Drewno wood. Nr. 185. Vol. 54. Polsko. p. 119-126.

6. Jelačić, D.; Moro, M.; Drábek, J.; Sujová, A., 2012: Motivation Factors in Wood processing Plants. Wood research 57 (2).

7. Kropivšek, J.; Jelačić, D.; Grošelj, P., 2011: Motivating employees of Slovenian and Croatian wood industry companies in times of economic downturn, Drvna industrija, 62(2): 97-103. doi: 10.5552/drind.2011.1040

8. Potkány, M., 2008: Personnel Outsourcing Processes, In: Ekonomie a management: vědecký ekonomický časopis. 11(4): 53-62.

9. Vetráková, M.; Seková, M.; Duurian, J., 2001: Ludské zdroje a ich riadenie. 1. vyd. Banská Bystrica : Univerzita Mateja Bela, p. 205.

10. StatSoft, Inc. 2004. STATISTICA (data analysis software system), version 7. Www.statsoft.com.

11. Scheer, L., 2007. Biometria. Vysokoškolská učebnica. Technická univerzita vo Zvolene, 2007.

\section{Corresponding address:}

Assoc. prof. Ing. MILOŠ HITKA, PhD. Department of Enterprise Management Faculty of Wood Sciences and Technology

Technical University in Zvolen

T. G. Masaryka 24

96053 Zvolen, SLOVAKIA

e-mail: hitka@tuzvo.sk 